\title{
Sustainable tourism development: ingenuity in marketing strategy
}

\author{
U. Jamrozy \\ Alliant International University, California, USA
}

\begin{abstract}
Small countries with exceptional natural beauty and unique cultural resources often look towards tourism development as an economic growth strategy. However, communities often disagree on the nature of development strategies. Supported by NGOs, sustainable tourism often is developed from the grassroots up. On the government side, the country's tourism organizations are pressured to find economic resources that stimulate economic growth. The strategy calls for outside investors. This paper proposes commitment to ingenuity in marketing strategy that encourages collaboration among stakeholders. It stipulates that outside investment can be sustainable without undermining the social and natural viability of the communities in the country. This sustainable marketing strategy suggests injecting the country's economy with external investments. The case study (e.g. sustainable eco-resort, eco-village, and arts-center) proposes major financial investments and commitment to sustainable operations. Based on network systems theory, the investments will only be sustainable if linked to other stakeholders and actors in the system. The created "marketing buzz" needs to have a catalytic effect internally: it will provide incentives for the communities for creating a vibrant "sustainable tourism identity" and a sustainable place branding strategy.
\end{abstract}

Keywords: sustainable tourism, marketing strategy, marketing network systems, sustainable investment strategy, place branding.

\section{Introduction}

Countries and regions with considerable natural and cultural resources look towards tourism when stimulating their sustainable development activities. Nongovernmental organizations often collaborate with local grassroots companies 
and entrepreneurs encouraging business development while protecting the resources. Governmental agencies and tourism development and marketing associations promote the country or region for sustainable economic growth and investments. Objectives and procedures may vary but sustainability should be the underlying motivation for all agencies. Tourism marketing agencies face the challenge of matching more sustainable tourism products with the appropriate target market. Often, their marketing and development strategies are too broad and vaguely defined to be effective. This paper examines network marketing systems as a foundation for more collaborative effective marketing strategies. Through network connections and collaboration tourism enterprises create synergies rather than compete with each other. This study further examines the case of Montenegro and suggests how a strong commitment towards sustainability could provide catalytic effects for sustainable development and create a positive brand image among targeted tourist populations.

\section{Conceptual foundation}

This paper proposes a sustainable marketing strategy based on a collaborative network marketing approach. Collaborative networking occurs at various levels, including all of the agencies in a country or region interested in sustainable development, all of the tourism organizations and businesses engaging in sustainable tourism development, all agencies creating a destination image, finally reflecting on a country's sustainable place image and sustainability identity.

\subsection{Network marketing}

Over the last decades, marketing evolved from a production and sales orientation towards a consumer and relationship marketing orientation. Marketing not only required a shift from tangible goods to services marketing but also a shift from product or performance development towards customer and stakeholder relationship marketing. Relationship marketing, defined as "a strategy to attract, maintain, and enhance customer relationships" [1] is marketing "to manage a firm's relationships" [1]. In the past, the strategy to build quality tourism attractions sufficed to attract many customers, but in a more competitive environment, smaller and medium sized enterprises only survive through regional collaborations and stakeholder involvement.

Beyond creating customer relationships, marketing itself can be seen as relationships, networks and interaction [2]. Mattsson [3] advanced the "relationship marketing" and the "markets-as-networks" approaches and explained how networks offer an extended version of relationship marketing when various criteria were met. The author explained how the traditional marketing mix approach evolved into a network approach based on a) the theoretical foundations, b) the character of the exchange, c) the system within the exchange takes place, and finally, its marketing management implications. He elaborated how the traditional marketing mix approach is based on monopolistic 
competition and simple dyadic economic exchanges. The transactions are distinctly taking place in a certain time period, within a market divided into clear market segments. Marketing management engages in planning and control driven by market analysis and research and sales results. In contrast, network marketing is more complex and interdependent. The marketing theory for networks is not solely based on economics, but derived from dynamic economics, sociology and organizational theory. Exchanges in networks take place through interdependent interactions that create valuable relationships over a long term time period. These relationships include third parties, often subnetworks are created. The boundaries of the markets are unclear. The marketing strategy is more holistic and focuses on organizational and inter-functional coordination. Mattsson [3] suggested examining the value, structure and dynamics of the networks more clearly. While most of the markets-as-networks research originated in industrial marketing and emphasized supplier relationships, many network relationships can be created between organizations and communities. Prahalad and Ramaswamy [4] illustrated an interesting model of "experience environments and networks: ....conceptually different from company centric supply chains, experience networks comprise non-linear, nonsequential interactions among companies, institutions and customer communities." Countries and regions are very complex tourism environments and work best if integrated into the country's network of economies and regions. The theoretical approach is based on the triple bottom line of sustainable development rather than pure economic exchanges, tourism is interdependent with other sustainable development activities and its boundaries are fuzzy. Beyond marketing and promotion, tourism agencies are involved in sustainable development projects and the country and its stakeholders benefit from a destination image by creating a sustainable country brand.

\subsection{Stakeholder involvement}

Stakeholders are the creators of country's identity. Stakeholder theory asks for stakeholder involvement in decision and policy making. Morgan et al. [5] demonstrated in an elaborate case study the role of stakeholders in destination branding. They examined the political processes involved while creating synergies between public and private sector stakeholders. The success of the destination brand is "based on a vision which is founded on intensive stakeholder, consumer and competitor research and which is expressed with care and discipline in everything that communicates the brand's personality" [5]. The authors explained that "country branding is not merely a rational marketing activity but a political act based on issues such as local pride" [5]. This stakeholder vision for product development can be extended to more integrated sustainable marketing strategies. For tourism marketing strategies, it needs to be acknowledged that traditional destination branding is not effective anymore in a global environment, that branding is connected to the complexity of a place, and that all stakeholders needed to be involved in the process. The proposed marketing strategy illustration is built on networks and stakeholder collaboration. A more sustainable approach provides a macro holistic view of marketing and 
integrates economic viability, social equity and environmental responsibilities. The paradigm shift includes changes in philosophy, such as adopting a theoretical (eco)-system community perspective, a focus on dynamic "holistic exchanges", and goals such as quality of life in a just and diverse society. The Sustainable Marketing Strategy Network (Figure 1) is designed to introduce an integrated system approach to marketing. The principle propositions made are that sustainable marketing decisions are dynamically influencing each other and are based on partnerships and shared visions of sustainability.

\subsection{Sustainable marketing strategy network}

The proposed sustainable marketing strategy network demonstrates a marketing system approach. A country or region's sustainable development philosophy and goals are correlated to the goals of sustainable tourism development. Sustainable marketing strategy suggests that through a commitment to sustainability in tourism enterprise development, the entrepreneurs will develop a strong destination identity. This identity then will determine the promoted country brand and destination image and enhance the support for country sustainable development goals. The cycle concludes if this encourages further sustainable tourism projects. In this model sustainable development and sustainable marketing strategy in tourism do not compete, but instead, create synergies.

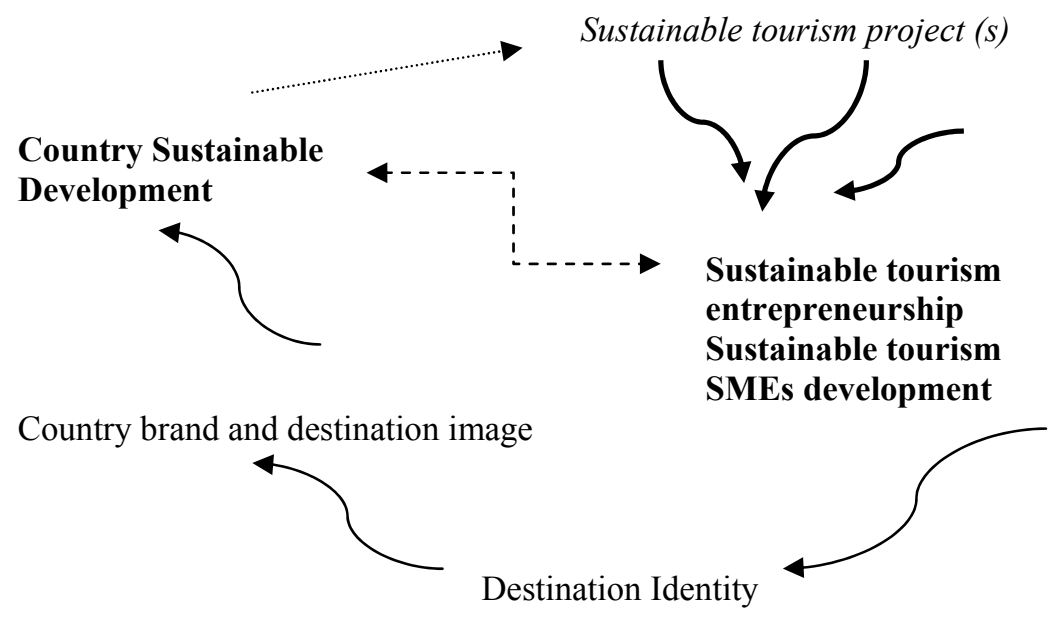

Figure 1: $\quad$ Sustainable marketing strategy network.

\section{Case study}

The following case study illustrates the network competencies of sustainable development and tourism and sustainable agencies in a country, potential sustainable tourism projects and their sustainable marketing strategies and the 
resulting synergies of sustainable brand image for the country. Sustainable marketing strategies were proposed after careful customized analysis of resources and potential.

\subsection{Montenegro}

Montenegro is a country with exceptional natural beauty and unique resources. As a tourism destination, it has mass tourism appeal due to inexpensive accommodation and limited tourism services and activities. Largely dependent on the organized mass tourism market, the tourism economy suffers if large operators pull out of the market. A more focused target strategy on niche markets and independent travelers would set the trend for a more sophisticated and sustainable tourism destination. The tourism master plan calls for a higher quality tourism product, the country's master development plan calls for more sustainable development. The two objectives synergistically create the foundation for a vibrant sustainable tourism industry.

While many destinations envision more sustainable economic development, fewer countries or region have the natural, cultural and economic resources to implement such plans. Montenegro has identified its resources and now, needs investors to realize its potential. Injections into high quality sustainable tourism development can foster further development at the levels of entrepreneurship and small and medium sized enterprises. As a result, such integrated sustainable development will create a more unique positive identity that will benefit nation branding strategies and contribute to the country's overall sustainable development system. The sustainable tourism projects will inject the energy into the system.

\subsubsection{Tourism project Velika Plaza: a luxury eco-tourism resort}

This project proposes the sustainable development of a beach region along the Mediterranean coast. It demonstrates commitment to the eco-resort principle.

3.1.1.1 Demand The eco-tourist is a well educated sophisticated traveler who demands beautiful pristine environments with educational opportunities. Today's eco traveler is highly aware of opportunities in Costa Rica, Belize, Ecuador and other South American eco-destinations. They know how to distinguish between green washed landscaped products and the authentic eco-experience. Due to long-haul travel environmental, economic, and time costs, European travelers will demand European eco-destinations. North American travelers will demand a combination of eco travel with prestigious Europe Travel. Spain and Italy are advancing fast to gain that position, but both still have a strong image with the mass tourism market. Montenegro has the advantage of undeveloped resources that can be developed in a sustainable way attaining a very unique market position.

3.1.1.2 Product This sandy beach region needs careful development to sustain its unique un-spoilt coastal resource. The product needs the development attention and sustainability commitment that makes it highly unique versus its 
Mediterranean competitors. The country could find developers for a $3 \mathrm{~km}$ stretch at the border of the Velika Plaza area that would be reserved for highquality, low-density, sustainable eco-tourism. This development would not only fit the criteria for nature-based tourism, but would demonstrate sustainable building criteria based on LEED (Leader in Energy and Environmental Design) or other country equivalents for green building design. Hotels and luxury destination resorts have recognized the economic and environmental importance of committing to higher standards and gaining market positioning benefits. In addition to exceeding green building criteria, investors would have experience in similar eco-tourism development projects: a) the resort would be educational about sustainability, natural resources and local culture, b) resort management would establish relationships with the local community system through its staff, community conservation projects, and economic, cultural workshops and development projects, and c) create memorable experiences for the tourists (spa, wellness, local cuisine restaurants, nature experiences). Following these criteria, the luxury resort would not demonstrate static building criteria but create a vibrant, dynamic demand for further sustainable development.

\subsubsection{Tourism project: Lake Skadar. A quality eco-tourism village}

This project proposes the sustainable development in delicate lake region. It demonstrates commitment to sustainable community development.

3.1.2.1 Demand Eco-Tourists are seeking experiences for themselves or among their families or like-minded travelers. This segment of the market is searching for quality nature-based tourism activities that do not leave a negative impact on the environment. They demand eco-lodge type accommodation but do not want to feel restricted by a resort-enclave. They want to participate in nature based activities and explore the local culture. Traditional mass tourism developments offer recreation equipment rentals, recreation programming and "animateurs" as well as the complete "all-inclusive" recreation experience. However, these developments don't fulfill the need for exploration, adventure and learning. The size of this market is relatively large, ranging from individual travelers (FIT), to families and mature adults. Through marketing, these segments will respond well to "quality eco-experiences" instead of the standardized vacation offers.

3.1.2.2 Product The Lake Skadar region offers superior flora and fauna and a leisurely vacation setting. We propose to find developers for a high-end ecolodge based vacation village, that will be integrated into eco-based regional development. Companies have developed nature-based regions, trails, and experiences while preserving the natural resources and adding unique value to the outdoor activities. A developer would build eco-lodges with similar green building standards and landscape planning. In addition to exceeding green building criteria, investors would have experience in similar eco-village projects: a) the eco-village would be educational about sustainability, natural resources and local culture; b) the eco-village would be integrated into the local community system through its staff, community conservation projects, and economic, cultural workshops and development projects, and c) create 
memorable, nature based and soft adventure-based activities for the tourists (hike and bike trails, fishing and boating opportunities, interpretive walks, and regional sight-experiencing tours). Following these criteria, the eco-village would not demonstrate static building criteria but create a vibrant, dynamic demand for further sustainable development.

\subsubsection{Tourism project Cetinje, Arts and Heritage Center}

This project proposes the sustainable development of an urban region. It demonstrates commitment to urban quality of life and entrepreneurship development.

3.1.3.1 Demand The modern and sophisticated traveler demands a heritage tourism environment that is neither "stuffy" nor "Disney-like". Cultural centers and museums have responded with more interactive media displays and "edutainment". Still, an isolated museum or innovative attraction, does not give an incentive to select a place as a tourism destination, or at least, to take a side trip along a scenic tourism route. In comparison to historic cities, heritage tourism destinations, are aware and interpret the past through the lens of evolving generations. Heritage tourists demand an authentic representation of the past without sacrificing a present-day tourism experience. Rather than developing a museum, urban areas are now developing historical or cultural precincts that integrate the local with the tourism economy.

3.1.3.2 Product As the old capital city with many historic buildings, Cetinje has a rich cultural heritage, originating from a diverse culture and printing industry. We propose to develop an arts and heritage center that integrates current art entrepreneurship and heritage interpretation. The developer would invest in a historical complex, renovate within sustainability standards and create a vibrant business precinct where locals and tourists meet. A few arts centers exemplify such complex cultural environments. The proposed project provides a venue for theatre and arts performances, houses quality local cuisine restaurants, has a large plaza/ courtyard for outdoor performances, and provides space for artist's studios, galleries and businesses. A developer would renovate old buildings with green building standards and landscape planning. In addition to exceeding green building criteria, investors would have experience in similar heritage tourism or urban design projects: a) the complex would be educational about sustainability, entrepreneurship and vibrant local culture; b) the urban precinct would be integrated into the local community system through its staff, community cultural projects, and economic workshops and development projects, and c) create memorable, heritage and arts based tourism experiences (theatre and play staging the diverse cultural heritage; arts studios for watching and participating in the creation of arts; shopping and enjoyment of culturally unique retail and restaurant opportunities, a sustainable business incubator center). Following these criteria, the arts and heritage center would not demonstrate static building criteria but create a vibrant, dynamic demand for further sustainable development. 


\subsection{Summary: integration of projects into sustainable development}

All three projects are quality investment projects that will generate attention ("creating a marketing buzz"). They require a careful search of potential investors that demonstrate commitment to sustainability principles. Investors will have to be convinced that Montenegro offers resources and benefits to them to make such state of the art projects worthwhile to them. For Montenegro, the projects will "create a buzz" in the tourism industry, among economic developers for large, medium and small enterprises and potential entrepreneurs. It will provide models and incentives to create a dynamic economy.

\section{Conclusion}

The purpose of this paper was to demonstrate how commitment towards sustainability and collaborative network marketing can create synergies that enhance further sustainable development. Within this system sustainable development objectives do not need to compete with tourism marketing practices. Rather, within the sustainability network system, sustainability goals are interrelated and interdependent and support each other. Sustainable destination images are based on sustainable tourism product strategies and create holistic country brand images encouraging further sustainable development in the country. The proposed sustainable marketing strategies are illustrated by a case study.

\section{References}

[1] Grönroos, C. Relationship marketing logic. Asia-Australia Marketing Journal, 4(1), 7-18, 1996

[2] Gummesson, E. Relationship Marketing. From 4Ps to 30Rs, Malmoe, LiberHermods, 1995.

[3] Mattsson, L.-G. "Relationship marketing" and the "markets-as-networks approach"- A comparative analysis of two evolving streams of research. Journal of Marketing Management, 13, 447-461, 1997.

[4] Prahalad, C.K., Ramaswamy, V. The new frontier of experience innovation. MIT Sloan Management Review, Summer, 12-18, 2003.

[5] Morgan, N.J., Pritchard, A., Piggott, R. Destination branding and the role of the stakeholders: The case of New Zealand. Journal of Vacation Marketing 9(3), 285-299, 2003. 